\title{
Epidemiology of Substance Abuse in Bangladesh: A Narrative Review
}

\section{Mohit Kamal $^{1 *}$, Huq ${ }^{2}$, Mali $\mathrm{B}^{3}$, Akter $\mathrm{H}^{3}$ and Arafat SMY4}

${ }^{1}$ Department Psychotherapy, National Institute of Mental Health, Dhaka, Bangladesh

${ }^{2}$ School of Public Health, Independent University, Bangladesh

${ }^{3}$ Department of Nursing, Bangabandhu Sheikh Mujib Medical University, Bangladesh.

${ }^{4}$ Department of Psychiatry, Bangabandhu Sheikh Mujib Medical University, Dhaka, Bangladesh

\begin{abstract}
Background: Substance abuse is an important public health and social problem in Bangladesh. The menace of substance has been increasing day by day in the country.

Objectives: This review was aimed to look into the epidemiology of substance abuse in Bangladesh based on recent literatures.

Methods: Search was done in PubMed, PubMed Central, Google Scholar, and Bangla JOL with searching keywords till March 2018. After considering inclusion and exclusion criteria total 15 articles were selected for review.

Results: From the pooled data the review revealed majority of the respondents were less than 30 years of age, $94.17 \%$ were male, $62.90 \%$ were unmarried, $94.17 \%$ from urban background, and $19.66 \%$ were businessman. Peer pressure was found as the commonest risk factors (54.69\%) followed by anger or impulse issues $(41.87 \%)$ and availability of drugs $(41.17 \%)$ were considerable risk factors. Heroin was found as a first choice of drug followed by yaba and cannabis.
\end{abstract}

Conclusion: This review revealed early adulthood was more risky years, males are mostly affected by drugs, peer pressure was most significant influencing risk factor and heroin is the mostly expected drug in Bangladesh.

Keywords: Substance abuse; Bangladesh; Drug abuse; Epidemiology; Heroin; Yaba; Demography

\section{Introduction}

Substance abuse is recognized as an important public health and social problem in Bangladesh [1,2]. The incidence of drug abuse has been increasing day by day in a developing country like Bangladesh [2]. Drug addiction hampers the mental well-being of an individual as well as it causes lots of physical complications [2]. In terms of geographical location Bangladesh is situated in the central point of the world's biggest growing narcotics zone: the 'golden crescent' (Afghanistan, Pakistan, and Iran) and the 'golden triangle' (Myanmar, Laos, and Thailand). So, the country has become a major transit point for drug dealers [3]. They are routing their shipments through this country to the markets of other parts of the world including Europe, Africa and America. Besides this, India, which is an important producer of opium and other substances located around Bangladesh. Though there was no available exact estimation of substance abusers in Bangladesh, on the basis of different and statistics, it can be estimated that the number may be more than 6 million and these people spend over 70 million BDT every day on illegal narcotics [3]. The major illicit drugs available in Bangladesh are opium derivatives (heroin, pethidine), cannabis (marijuana, ganja, chorosh, bhang, hashish), stimulants (yaba, cocaine), sleeping pills, cough syrup (phensidyl, dexpotent etc.) and few others [1,4]. The problem is increasing day by day and threatening the nation. Males are being affected by drugs more than the females [1] and early adulthood is the vulnerable age for abusing drugs. Preferable drugs are heroin, yaba, cannabis, followed by few others. However, it is under studied in the country. No nation-wide prevalence study has been published yet. There is dearth of epidemiological research on drug abuse. We aimed to look into the epidemiology of drug use in Bangladesh based on the existing literature.

\section{Methods}

For selecting article search was done in electronic data bases (PubMed, PubMed Central, Google Scholar \& Bangla JOL) with searching key words till March 2018. Initial screening was done by analyzing the titles, then abstract was reviewed and finally full articles were downloaded and studied. After exclusion of duplication, screening, finally selection was done on basis of inclusion and exclusion criteria and finally 15 articles were selected for review.

\section{Searching words}

Substance abuse in Bangladesh, drugs in Bangladesh, drug abuse in Bangladesh, yaba in Bangladesh, addiction in Bangladesh, cannabis in Bangladesh, substance use disorder in Bangladesh, substance related disorder in Bangladesh, prevalence of substance use/related disorder in Bangladesh, demography of substance users in Bangladesh

\section{Inclusion criteria}

1. Full downloadable original articles in pdf form

2. Articles regarding substance abuse in Bangladesh

3. English language.

*Corresponding author: Mohit Kamal, Professor and Head of Psychotherapy, National Institute of Mental Health, Dhaka, Bangladesh, Tel: +8801711832955; E-mail: drmohitkamal@yahoo.com

Received July 13, 2018; Accepted July 26, 2018; Published August 10, 2018

Citation: Kamal M, Huq N, Mali B, Akter H, Arafat SMY (2018) Epidemiology of Substance Abuse in Bangladesh: A Narrative Review. J Ment Disord Treat 4: 165. doi:10.4172/2471-271X.1000165

Copyright: $\odot 2018$ Kamal M, et al. This is an open-access article distributed unde the terms of the Creative Commons Attribution License, which permits unrestricted use, distribution, and reproduction in any medium, provided the original author and source are credited. 


\section{Exclusion criteria}

1. Review articles

2. Articles of single substances

3. Article of suicide outside the Bangladesh demography.

Variables: Age, sex, occupation, status, residence, marital status, choice of drug, route of drug, identifiable risk factors, reason for relapse, and sources of money, were considered as the variables of the study.

Permission: As the data includes only online available previously published information, no formal ethical clearance was needed.

Data analysis: All selected articles were scrutinized for the variables and data were pooled to create a single source. Percentages were calculated based on summation of the total samples of the mentioned article and summation of corresponding variable frequencies. There were multiple responses and different pattern of variables in different articles. So total number of sample and total frequencies were mentioned in every variables separately.

\section{Results}

The mean age of the respondents was 28.10 years with ranges from 10-50 years. Majority of the respondents were less than 30 years of age. About $94 \%$ of the respondents were male, $63 \%$ were unmarried, $94 \%$ from urban background, 33\% were unemployed and 51\% were from joint family (Table 1). Peer pressure was found as the most influencing risk factors. About $55 \%$ of the respondents take substance due to peer pressure, $41 \%$ were influenced by availability of drugs, $34 \%$ took drug to get pleasure, and $27 \%$ started for their curiosity (Table 2). Heroin was the choice of drug in this review. About $67 \%$ of respondents considered heroin as their choice of drug, $44 \%$ considered yaba, and $39 \%$ considered cannabis as drugs of choice (Table 2). For abusing drugs $65.49 \%$ of the respondents arranged money from criminal activities, $64.28 \%$ from family and $33.80 \%$ from own income. Majority of the respondents (63.45\%) took drug orally, 57.39\% took through inhalation, and only about $9 \%$ in injectable form (Table 3). But, a substantial portion of respondents took drug in multiple routs. Moreover, abusing more than one substance is an important concern (Table 4).

\section{Discussion}

In this paper, epidemiology of substance addiction in Bangladesh was reviewed. About $94 \%$ of the respondents were male that signifies the gender representation of substance use in Bangladesh. Repeated studies in Bangladesh revealed that males are being addicted more than the females [4-14]. This review found unmarried (62.90\%) respondents were more likely to take substances than married and others those are supported by other studies $[3,10]$. However, Maehira et al., found most of the respondents (59\%) were divorced/separated/widower/ widow [5]. Most of the respondents (94.17\%) were urban background which was found in multiple studies [3,8,12-14]. The situation can be explained by the sample distribution and place of the studies. Most of the studies were conducted in clinical settings in urban areas. As a result, such urban rural distribution was found. Study revealed almost similar distribution in regards to the educational achievements, interestingly more respondents were prevalent in graduate class (Table 2). Unemployment and businessmen were more prone for substance abuse which was found in multiple studies $[2,8,10,11,13,14]$. Unemployment may act as both cause or effect of substance abuse. However, none of the studies studied the relationship of unemployment and substance abuse. In other ways, Islam and Hossain, found students were more take substance than unemployment and businessman [11]. Peer pressure contributed highest as a risk factor followed by anger or impulse, availability and getting pleasure which was supported by multiple original studies $[1,3,11,14,15]$. Heroin as a most choice able drug of majority of the respondents followed by yaba and cannabis those are repeatedly found in other study $[1,3,4,6-9,11,12,14,15]$. In current scenario of the country yaba might be the most abused drug and future studies would reveal that.

\begin{tabular}{|c|c|c|c|c|c|c|}
\hline Year & Author & City & Location & Sample Size & Type of study & Investigated issue \\
\hline 2014 & Zaman et al. [1] & Dhaka & СТC & 300 & Cross-Sectional & Psychosocial illness in detoxification center \\
\hline 2013 & Maehira et al. [5] & Dhaka & Private Hospital & 260 & Prospective cohort & $\begin{array}{l}\text { Factors associated with relapse in detoxification- } \\
\text { rehabilitation programme }\end{array}$ \\
\hline 2010 & Roy et al. [6] & Dhaka & BSMMU and CTC & 500 & Case Control & Personality Traits of Substance Users \\
\hline 2013 & Hossain et al. [7] & Dhaka & СТС & 1076 & Cross-Sectional & $\begin{array}{l}\text { Sex-habit and STIs among drug abusers in } \\
\text { Detoxification }\end{array}$ \\
\hline 2013 & Riya et al. [8] & Dhaka & СТС & 150 & Cross-Sectional & $\begin{array}{l}\text { Pattern of Drug Abuse in Addiction Rehabilitation } \\
\text { Centers }\end{array}$ \\
\hline 2015 & Islam et al. [2] & Mymensingh & Private Hospital & 38 & Cross-Sectional & Social Impact of Drug Addiction \\
\hline 2015 & Khan [9] & Munshiganj & Community & 182 & Cross-Sectional & Debunking the Drug Abuse-Crime in Urban Youths \\
\hline 2017 & $\begin{array}{l}\text { Hasam and } \\
\text { Mushahid [10] }\end{array}$ & Sylhet & Private Hospital & 99 & $\begin{array}{l}\text { Cross-Sectional-multi } \\
\text { center }\end{array}$ & Causes of Drug Addiction in Urban Life \\
\hline 2014 & Islam et al. [11] & $\begin{array}{l}\text { Across } \\
\text { Bangladesh }\end{array}$ & $\begin{array}{l}\text { Universities, public } \\
\text { institutions }\end{array}$ & 100 & Descriptive & Impact of Drug abuse \\
\hline 2017 & Mohit et al. [3] & Dhaka & Private Hospital & 306 & Descriptive & $\begin{array}{l}\text { Prevalence and Patterns of Substance Abuse among } \\
\text { Male Patients }\end{array}$ \\
\hline 2017 & Roy and Mian [12] & Sylhet & Private Hospital & 155 & Descriptive & $\begin{array}{l}\text { Socio-Demographic and Clinical Profile of Substance } \\
\text { Abusers }\end{array}$ \\
\hline 2017 & Soron et al. [13] & Dhaka & NIMH and CTC & 101 & Descriptive & Social and Family Determinants of Substance Abuse \\
\hline 2016 & Maruf et al. [14] & Dhaka & Private Hospital & 105 & Descriptive & Pattern of Substance Use in De-addiction Clinic \\
\hline 2018 & Hossain et al. [15] & Dhaka & СТС & 120 & Descriptive & $\begin{array}{l}\text { Oral and Dental Diseases and Oral Hygiene Practices } \\
\text { among Illicit Drug Abusers }\end{array}$ \\
\hline 2017 & Ahad et al. [4] & Sylhet & Private Hospital & 42 & Descriptive & Socioeconomic Status of Young Drug Addicts \\
\hline
\end{tabular}

CTC- Central Drug Addiction Treatment Centre

BSMMU- Bangabandhu Sheikh Mujib Medical University

NIMH- National Institute of Mental Health 
Citation: Kamal M, Huq N, Mali B, Akter H, Arafat SMY (2018) Epidemiology of Substance Abuse in Bangladesh: A Narrative Review. J Ment Disord Treat 4: 165. doi:10.4172/2471-271X.1000165

Page 3 of 4

\begin{tabular}{|c|c|c|c|}
\hline Demographic Variable & Frequency & Percentage & Total sample \\
\hline \multicolumn{4}{|l|}{ Sex } \\
\hline Male & 856 & 94.17 & 909 \\
\hline Female & 53 & 5.83 & 909 \\
\hline \multicolumn{4}{|l|}{ Marital Status } \\
\hline Married & 332 & 46.82 & 709 \\
\hline Unmarried & 446 & 62.90 & 709 \\
\hline Divorce & 28 & 3.94 & 709 \\
\hline Widow & 2 & 0.97 & 206 \\
\hline \multicolumn{4}{|l|}{ Habitat } \\
\hline Urban & 834 & 94.17 & 1067 \\
\hline Rural & 233 & 21.84 & 1067 \\
\hline Missing & 28 & 7.8 & 1067 \\
\hline \multicolumn{4}{|l|}{ Occupation } \\
\hline Student & 182 & 19.34 & 941 \\
\hline Unemployment & 271 & 32.22 & 841 \\
\hline Business & 185 & 19.66 & 941 \\
\hline Service & 142 & 16.86 & 842 \\
\hline Driver & 5 & 3.50 & 143 \\
\hline Cultivator & 5 & 4.95 & 101 \\
\hline Day labor & 19 & 10.50 & 181 \\
\hline Other & 15 & 5.24 & 286 \\
\hline Housewife & 4 & 3.81 & 105 \\
\hline Retired & 1 & 0.95 & 105 \\
\hline \multicolumn{4}{|l|}{ Education } \\
\hline Illiterate & 61 & 23.55 & 259 \\
\hline Below SSC & 157 & 24.30 & 646 \\
\hline SSC & 171 & 22.95 & 745 \\
\hline HSC & 193 & 19.97 & 966 \\
\hline Graduate & 278 & 26.07 & 1066 \\
\hline Postgraduate & 60 & 10.84 & 100 \\
\hline \multicolumn{4}{|l|}{ Type of family } \\
\hline Nuclear & 143 & 48.97 & 292 \\
\hline Joint & 149 & 51.03 & 292 \\
\hline
\end{tabular}

Table 2: Distribution of demographic variables of the respondents.

\begin{tabular}{|l|l|l|l|}
\hline Variable & Frequency & Percentage & Total sample \\
\hline Risk factors & & & \\
\hline Peer pressure & 710 & 54.69 & 1298 \\
\hline Getting pleasure & 155 & 34.06 & 405 \\
\hline Curiosity & 243 & 27.24 & 892 \\
\hline Depression & 57 & 19 & 300 \\
\hline Failure in love & 56 & 11.61 & 482 \\
\hline Loneliness & 12 & 4 & 300 \\
\hline Unemployment & 141 & 15.87 & 888 \\
\hline Frustration & 134 & 20.83 & 643 \\
\hline No reason & 17 & 10.96 & 155 \\
\hline Family problem & 252 & 34.14 & 738 \\
\hline Availability & 105 & 41.17 & 255 \\
\hline surrounding environment & 43 & 10.59 & 406 \\
\hline Anger/ Impulse & 170 & 41.87 & 406 \\
\hline Financial & 58 & 18.95 & 306 \\
\hline Relationship & 52 & 16.99 & 306 \\
\hline Family history & 27 & 8.82 & 306 \\
\hline Political issue & 11 & 3.59 & 306 \\
\hline Parental separation & 8 & 2.61 & 306 \\
\hline Death of loved ones & 4 & 1.30 & 306 \\
\hline Prescription & 3 & 1.93 & 155 \\
\hline Choice of drugs & 1625 & 66.98 & 2426 \\
\hline Heroin & & & \\
\hline & & & \\
\hline
\end{tabular}

\begin{tabular}{|l|l|l|l|}
\hline Phensidyl & 613 & 25.26 & 2426 \\
\hline Cannabis & 942 & 38.82 & 2426 \\
\hline Sedatives & 180 & 16.58 & 1085 \\
\hline Yaba & 596 & 44.37 & 1343 \\
\hline Danti & 30 & 10 & 300 \\
\hline Shisha/Hukka & 24 & 8 & 300 \\
\hline Cough syrup & 61 & 9.47 & 644 \\
\hline Injection & 136 & 7.06 & 1926 \\
\hline Alcohol & 303 & 27.72 & 1093 \\
\hline Pathedine & 168 & 22.76 & 738 \\
\hline Morphine & 12 & 2.63 & 456 \\
\hline Cocaine & 13 & 2.86 & 453 \\
\hline Reason to relapse & & & \\
\hline Peer influence & 69 & 18.64 & 370 \\
\hline Family-related problem & 44 & 11.89 & 370 \\
\hline Personal problems & 13 & 20.31 & 64 \\
\hline Drug craving, withdrawal & 6 & 9.37 & 64 \\
\hline symptoms & & & \\
\hline To enhance sexual power & 2 & 3.12 & 64 \\
\hline Psychological & 60 & 19.60 & 306 \\
\hline Anger/ Impose & 52 & 16.99 & 306 \\
\hline Frustration & 30 & 9.80 & 306 \\
\hline Loneliness & 26 & 8.49 & 306 \\
\hline Break up & 22 & 2.18 & 306 \\
\hline Environmental & 7 & 306 \\
\hline Occasion celebration & 12 & 306 \\
\hline Extra marital affair & & & \\
\hline Unemployment & & & \\
\hline Tahlo & & & \\
\hline
\end{tabular}

Table 3: Distribution of Risk factors, drugs choice, reasons for relapse, among the respondents.

\begin{tabular}{|l|c|c|c|}
\hline Variable Routes of drug & Frequency & Percentage & Total sample \\
\hline Oral & 356 & 63.45 & 561 \\
\hline Inhalation & 332 & 57.39 & 561 \\
\hline Injection & 50 & 8.91 & 561 \\
\hline Drug abuse in lifetime & \multicolumn{3}{|l|}{} \\
\hline Single drug & 105 & 35 & 300 \\
\hline Two drugs & 380 & 27.61 & 1376 \\
\hline Three drugs & 353 & 25.65 & 1376 \\
\hline Four drugs & 322 & 23.40 & 1376 \\
\hline Five drugs & 213 & 15.47 & 1376 \\
\hline Six drugs & 107 & 7.77 & 1376 \\
\hline
\end{tabular}

Table 4: Distribution of routes and number of drugs among the respondents.

\section{Conclusion}

The review revealed the recent epidemiology of substance abuse in Bangladesh. To the authors best knowledge this is the first study to explore the substance abuse in the country. Early adulthood, is risky part of life, abusers are mostly male, peer pressure is the most significant influencing risk factor and Heroin is the mostly expected drug. However, further systematic reviews would help to generalize the findings.

\section{References}

1. Zaman B, Ahmed SM, Hossain MM, Kamal MM (2014) Psychosocial illness among the drug abusers undergoing detoxification in Dhaka, Bangladesh South East Asia J Public Heal 4: 36-41.

2. Islam MA, Hossen MT, Hossain MK, Fatima K, Khatun M (2015) Impact of drug addiction on social environment focused in Mymensingh district. Res Agric Livest Fish 2: 411-417.

3. Mohit MA, Maruf MM, Ahmed H, Alam MT (2011) Depression and Physical Illnesses: an Update. Bangladesh Med J 40: 53-58. 
Citation: Kamal M, Huq N, Mali B, Akter H, Arafat SMY (2018) Epidemiology of Substance Abuse in Bangladesh: A Narrative Review. J Ment Disord Treat 4: 165. doi:10.4172/2471-271X.1000165

Page 4 of 4

4. Ahad MA, Chowdhury DM, Islam MB, Alam MF (2017) Socioeconomic Status of Young Drug Addicts in Sylhet City, Bangladesh. IOSR J Humanit Soc Sci 22: 84-91.

5. Maehira Y, Chowdhury E, Reza M, Drahozal R, Gayen T, et al. (2013) Factors associated with relapse into drug use among male and female attendees of a three-month drug detoxification-rehabilitation programme in Dhaka, Bangladesh: a prospective cohort study. Harm Reduct J 10: 14.

6. Roy J, Morshed NM, Qusar MMAS, Nahar JS, Miah MAS, Shah MA, et al. (2010) Personality Traits of Substance Users in Bangladesh. BSMMU J 3: 76-81.

7. Hossain KJ, Karim MR, Karim AMMN, Kamal MM (2013) Sex-habit and Sexually Transmitted Infection (STIs) Among The Drug Abusers Undergoing Detoxification. J Med 14: 5-10.

8. Riya S, Rahman M, Sadeque MZ, Kabir A, Umar BU (2013) Pattern of Drug Abuse among Patients in Some Selected Addiction Rehabilitation Centers in Dhaka City. Faridpur Med Coll J 8: 63-66.

9. Khan TH (2015) Debunking the Drug Abuse-Crime Interplay A Study on the Youths of Selected Urban Areas of Munshiganj District, Bangladesh. Soc Chang 9: 44-63.
10. Hasam MA, Mushahid M (2017) Drug Addiction in Urban Life of Bangladesh: A Sociological Study for Exploring the Causes. Asia Pacific J Multidiscip Res 5: 1-11.

11. Islam A, Hossain MF(2017) Drug abuse and its impact on Bangladesh. Int J Sociol Anthropol 9: 143-156.

12. Roy S, Miah MZ (2017) Socio-Demographic and Clinical Profile of Substance Abusers Attending a Regional Psychiatric Hospital in Sylhet, Bangladesh. J Addict Res Ther 8: 1000342.

13. Soron TR, Siddike PMA, Ahmed HU, Chowdhury CA (2017) Social and Family Determinants of Substance Abuse among the Patients of Two Hospitals in Bangladesh. J Addict Res Ther 8: 1000340.

14. Maruf MM, Khan MZR, Jahan N (2016) Pattern of Substance Use: Study in a De-addiction Clinic. Oman Med J.31: 327-331.

15. Hossain KMS, Kakoli AS, Mesbah SB, Mian AH (2018) Prevalence of Ora and Dental Diseases and Oral Hygiene Practices among Illicit Drug Abusers. J Alcohol Drug Depend 6: 1000301. 